\title{
Suppression of Sclerotinia Stem Rot of Soybean by Lactofen Herbicide Treatment
}

\author{
E. K. Dann, B. W. Diers, and R. Hammerschmidt
}

First and third authors: Department of Botany and Plant Pathology; second author: Department of Crop and Soil Sciences, Michigan State University, East Lansing 48824.

Current address of E. K. Dann: Department of Crop Sciences, University of Sydney, N.S.W. 2006, Australia.

Current address of B. W. Diers: Department of Crop Science, University of Illinois-Urbana, 1102 S. Goodwin Avenue, 61801.

Accepted for publication 20 April 1999.

ABSTRACT

\begin{abstract}
Dann, E. K., Diers, B. W., and Hammerschmidt, R. 1999. Suppression of Sclerotinia stem rot of soybean by lactofen herbicide treatment. Phytopathology 89:598-602.

Severity of Sclerotinia stem rot of soybean after treatment with lactofen (Cobra) and other herbicides was assessed in field experiments conducted in Michigan from 1995 to 1997. At sites where disease pressure was high, disease severity was reduced 40 to $60 \%$ compared with controls when lactofen was applied at the V3 (1995 and 1996) or R1 (1997) growth stages. Corresponding seed yields were unchanged or up to $20 \%$ greater when lactofen was applied at the R1 stage in 1997. Disease se-
\end{abstract}

verity was not reduced by lactofen treatments in years and at sites where disease pressure was low to medium, and corresponding yields often were reduced by $\approx 10 \%$. High levels of glyceollin accumulated in lactofen-injured leaves collected from field plots in 1996 and 1997. High glyceollin content in lactofen-treated leaves was associated with significant reductions in lesion size when leaves were challenge-inoculated with Sclerotinia sclerotiorum.

Additional keywords: diphenyl ether, protoporphyrinogen IX oxidase, Protox, white mold.
There are many agronomic and horticultural crops that exhibit altered disease responses after applications of registered herbicides $(2,15,17)$. Suppression or enhancement of disease incidence and severity by herbicide treatment can occur directly through single or combined effects on the pathogen, host, or surrounding microorganisms (15). Additionally, herbicides may indirectly affect disease levels by controlling weeds, which may eliminate alternative disease hosts or alter the microclimate (15).

The incidence and severity of Sclerotinia stem rot (white mold) disease of soybean has increased in the Midwestern production zones of the United States during the last decade (9). A contributing factor could be the decline in the number and potency of triazine (most commonly atrazine) herbicide applications used in corn production prior to soybean rotations. Triazine herbicides such as atrazine have a direct effect on Sclerotinia sclerotiorum, the cause of Sclerotinia stem rot of soybean and many other dicot crop plants. Laboratory studies have shown that carpogenic germination of $S$. sclerotiorum sclerotia is enhanced if sclerotia are incubated in soil containing atrazine. However, stipes and apothecia were malformed, and ascospores were not produced $(6,18)$. The reduced use of atrazine in combination with changes in agronomic practices, such as the trend toward no-till and narrower row spacing (9) and increased use of cultivars related to the Sclerotinia stem rot-susceptible cv. Williams 82, provides more favorable conditions for infection and Sclerotinia stem rot development.

Another example of a possible direct effect of a herbicide on a soybean pathogen and resulting disease is provided by Black et al. (5). Postemergent application of the diphenyl ether herbicide acifluorfen resulted in reduced disease intensity of Rhizoctonia foliar

Corresponding author: E. K. Dann; E-mail address: danne@agric.usyd.edu.au

Publication no. P-1999-0521-01R

(C) 1999 The American Phytopathological Society blight, caused by Rhizoctonia solani AG-1, and increased yields under low disease pressure. However, there was no such effect under high disease pressure. Mycelial growth and sclerotial production of two isolates were not significantly inhibited by field-strength concentrations when the fungus was grown on acifluorfen-amended potato dextrose agar (PDA).

An example of herbicide treatment affecting soybean defense responses is provided by studies of glyphosate $(14,16)$. Treatment of soybean with nonphytotoxic concentrations of glyphosate inhibited accumulation of glyceollin, the soybean phytoalexin, when inoculated with incompatible Pseudomonas syringae pv. glycinea or Phytophthora megasperma f. sp. glycinea. Resistance of hypocotyls to incompatible Phytophthora megasperma f. sp. glycinea was suppressed in glyphosate-treated seedlings. Hypersensitive cell death was observed in glyphosate-treated plants inoculated with incompatible Pseudomonas syringae pv. glycinea, despite an increase in bacterial numbers compared with untreated plants, which suggests resistance was suppressed only partially.

Our paper describes the effects of postemergent applications of diphenyl ether and other classes of herbicides on Sclerotinia stem rot in soybean. The study was initiated after growers reported reduced disease severity in soybean fields sprayed with lactofen (Cobra), a diphenyl ether herbicide. Field trials were conducted in Michigan from 1995 to 1997 to assess the effects of herbicide treatments on four soybean cultivars that differ in their reactions to Sclerotinia stem rot. Additional field studies were done to investigate herbicide-induced alterations to host biochemical defenses and how alterations may contribute to observed disease suppression.

\section{MATERIALS AND METHODS}

Treatments. Field trials were conducted during the 1995 to 1997 growing seasons at the Michigan State University research farms in Ingham County and at a producer's field in Bay County, 
MI. Sclerotinia stem rot-resistant cv. Northrup King (NK)S 19-90, moderately resistant cv. Corsoy 79, and susceptible cvs. Elgin 87 and Williams 82 were planted in seven-row plots, $6.1 \mathrm{~m}$ long with $17.8 \mathrm{~cm}$ between rows. The experiments were based on a splitplot randomized complete block design, with cultivars as main plots and treatments as subplots. The herbicide treatments, summarized in Table 1, were applied with appropriate adjuvants at the $\mathrm{V} 3$ or V4 growth stage (10) with a $\mathrm{CO}_{2}$-pressurized hand-held sprayer delivering 190 liters $\mathrm{ha}^{-1}$. Lactofen also was applied at the R1 growth stage in 1997. Water alone was applied each year as one control, and crop oil adjuvant at 1.17 liters ha $^{-1}$ was applied in 1997 as an additional control.

The Ingham County site was amended with S. sclerotiorum inoculum during the fall prior to sowing by incorporating crop trash containing sclerotia into the top $3 \mathrm{~cm}$ of soil and was irrigated daily during flowering to maintain humid canopy conditions. The Bay County site has a history of severe Sclerotinia stem rot and is in an environment favorable for natural infection and disease development. The trials were assessed for Sclerotinia stem rot severity at the R7 growth stage (10). Thirty plants per plot were rated on a scale of 0 to 3 , according to Grau et al. (12), in which $0=$ no symptoms, 1 = lesions on lateral branches only, $2=$ lesions on main stem but little or no effect on pod-fill, and $3=$ lesions on main stem resulting in plant death and poor pod-fill. A disease severity index (DSI) for each plot was calculated. Plots were harvested for seed yield determination $\approx 2$ weeks after the R8 stage (10). Analyses of variance were performed on the DSI and yield data separately for each year and site, using the Statistical Analysis System program (SAS Institute, Cary, NC).

Physiological effects. Duplicate samples of leaves were collected from NKS 19-90 and Williams 82 field plots at the Ingham County site in 1996, 3 days after V3 lactofen treatment. Leaves with only moderate herbicide injury were selected. Healthy upper leaves were collected in 19966 weeks after treatment, when plants had outgrown herbicide injury. Duplicate leaf samples were collected in 19974 days after $0.04,0.07$, and $0.11 \mathrm{~kg}$ a.i. ha ${ }^{-1}$ lactofen treatment at the V4 stage. One set of leaves from each collection time was stored at $-20^{\circ} \mathrm{C}$ and later extracted for measurement of the soybean phytoalexin glyceollin, as an indicator of induced defense. Each leaf in the second set of field leaves was inoculated on the day of collection with a 2.5 -mm-diameter mycelial plug of $S$. sclerotiorum taken from the margin of a colony grown on PDA at $21^{\circ} \mathrm{C}$. Resulting lesion diameters were measured after 2 days of incubation at room temperature.

Frozen leaf tissue was cut into 0.5 - to $1.0-\mathrm{cm}$ pieces, transferred to an Erlenmeyer flask, and extracted by covering overnight with $80 \%$ methanol ( 20 to $25 \mathrm{ml} / \mathrm{g}$ fresh weight), followed by boiling until $20 \%$ of the original volume remained. The resulting leaf extract was collected, and the flask was rinsed with 1 to $2 \mathrm{ml}$ of water. Extract and aqueous rinsate were combined and extracted three times with equal volumes of chloroform. Combined chloroform extracts were dried with anhydrous sodium sulfate. Chloroform was removed by rotary evaporation under reduced pressure. Resi- dues were resuspended in small volumes $(\approx 200 \mu \mathrm{l})$ of ethyl acetate, applied to silica gel $(250 \mu \mathrm{m})$ thin-layer chromatography plates containing fluorescent indicator (Redi/Plate, Silica Gel GF, Fisher Scientific, Itasca, IL), and developed in chloroform/methanol (100:10, $\mathrm{vol} / \mathrm{vol}$ ) solution. Bands migrating to the same $\mathrm{R}_{f}$ as the glyceollin standard (provided by M. Gijzen, Agriculture and Agri-Food Canada) were identified by fluorescence quenching under short-wave UV light. Bands were scraped from the plates, glyceollin was eluted from the silica gel with ethyl acetate, and ethyl acetate was removed under a flow of $\mathrm{N}_{2}$. Glyceollin isomers were separated and quantified by high-performance liquid chromatography with a $250 \times$ 4.6-mm silica column (Econosphere Silica 5U, Alltech Associates, Deerfield, IL) with 5\% isopropanol in hexane as the mobile phase and detected by absorption at $215 \mathrm{~nm}$. Elution times for isomers I,

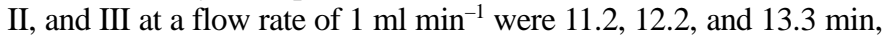
respectively. Each isomer was quantified by interpolating from curves prepared from published extinction coefficients (4) and absorbances obtained after injecting known amounts of isomers. Log-transformed data were subjected to a regression containing linear and quadratic trend analyses. Means of untransformed data are presented in Tables 2 and 3.

\section{RESULTS}

Field studies. Lactofen treatment caused severe foliar injury or burn within 1 day of application. Defoliation and malformation of developing trifoliate leaves also occurred; however, plants outgrew the injuries and appeared healthy within 3 weeks. There was no cultivar by treatment interaction for DSI and yield, so data for each site and year were combined across cultivars for each treatment for presentation (Table 4).

Disease severity and seed yields of water control plots varied across the two locations and 3 years studied (Table 4). Disease severity was greater at the irrigated Ingham County site than at the Bay County site in 1996 and 1997. The near absence of disease at Ingham in 1995 was attributed to unusually hot, drying winds during the growing season.

Disease severity at the Ingham County site was low in 1995 , and there were no differences between lactofen- and water-treated plots (Table 4). However, there was a significant yield reduction after lactofen treatment compared with water controls. Conversely, there was a significant reduction in DSI after lactofen treatment at the Bay County site, but no differences in seed yields.

There were significantly lower DSI for lactofen and acifluorfen treatments compared with the water control at the Ingham County site in 1996; however, corresponding yields were not greater. Interestingly, yields were reduced by imazethapyr and chlorimuron ethyl plus thifensulfuron methyl treatments at the Ingham County site, despite an absence of macroscopic injury symptoms after application (Table 4). There were no differences in DSI between any herbicide treatment and water control at the Bay County site in 1996, but there was a significant reduction in yield after lactofen treatment (Table 4).

TABLE 1. Summary of herbicides applied to field plots in 1995 to 1997

\begin{tabular}{llcc}
\hline Common name & Brand name and manufacturer & Year tested & Concentration $\left(\mathrm{kg}^{\left.\mathrm{a} . \mathrm{i} . \mathrm{ha}^{-1}\right)}\right.$ \\
\hline Lactofen & Cobra, Valent USA Corp. & 1995 & 0.11 \\
& & 1996 & 0.11 \\
Acifluorfen & Blazer, BASF Corp. & 1997 & $0.04,0.07,0.11,0.23$ \\
& & 1996 & 0.42 \\
Fomesafen & Reflex, Zeneca Ag Products & 1997 & 0.42 \\
Fomesafen & Flexstar, Zeneca Ag Products & 1996 & 0.28 \\
Imazethapyr & Pursuit, American Cyanamid Co. & 1997 & 0.25 \\
& & 1996 & 0.07 \\
Bentazon & Basagran, BASF Corp. & 1997 & 0.07 \\
Chlorimuron ethyl + thifensulfuron methyl & Classic, Du Pont; & 1996 & 0.84 \\
& Pinnacle, Du Pont & 1996 & 0.004 each \\
\hline
\end{tabular}


There were significant reductions in disease severity at Ingham County in 1997 after treatment with each concentration of lactofen at the R1 growth stage, and yields were greater after 0.07 and $0.11 \mathrm{~kg}$ a.i. $\mathrm{ha}^{-1}$ lactofen treatments compared with the water control (Table 4). There were no differences in DSI between any herbicide treatment and the water control at Bay County in 1997; however, the yields for all R1 lactofen treatments were significantly lower than the water control.

Physiological effects. Three days after $0.11 \mathrm{~kg}$ a.i. $\mathrm{ha}^{-1}$ lactofen treatment at the V3 growth stage in 1996 leaves contained large areas of brown necrosis that were not present on water-treated leaves. S. sclerotiorum lesion diameters on lactofen-treated leaves were significantly smaller than on the respective water controls for each cultivar (Table 2). Glyceollin was not detected in water control treatments; however, it accumulated in lactofen-treated leaves. Glyceollin accumulation was five times greater in NK S19-90 than in Williams 82 (Table 2). Six weeks after V3 treatment, there were no macroscopic injury symptoms on upper leaves collected from any treatment. There were no differences in $S$. sclerotiorum lesion diameters among treatments for either cultivar. Lesions on leaves from older plants were smaller compared with those on control leaves collected 3 days after treatment, possibly suggesting age-related resistance. There were no differences in glyceollin content of leaves 6 weeks after lactofen treatment (Table 2).

Four days after V4 treatment in 1997 herbicide injury after $0.11 \mathrm{~kg}$ a.i. $\mathrm{ha}^{-1}$ lactofen treatment was worse than after 0.04 or $0.07 \mathrm{~kg}$ a.i. ha ${ }^{-1}$ lactofen treatment, although injury was not quantified. Sclerotinia sp. lesions on leaves treated with any rate of lactofen were significantly smaller than water controls for each cultivar but were not significantly different among the three rates (Table 3). Glyceollin levels for each cultivar were significantly greater than water controls for each lactofen rate; however, levels were not significantly different among lactofen rates. Although glyceollin response appeared to be linear with increasing lactofen rates, it was not demonstrated statistically. Glyceollin accumulation was approximately twice as high for NK S19-90 as for Williams 82 after lactofen treatment, illustrating a significant cultivar by treatment interaction (Table 3 ).

\section{DISCUSSION}

Three years of field studies in Michigan demonstrated suppression of Sclerotinia stem rot disease in plots treated with the herbicide lactofen (Cobra). However, disease was not suppressed by lactofen in every situation. The best suppression was observed

TABLE 2. Resistance response of field soybean leaves 3 days or 6 weeks after V3 lactofen treatment in 1996

\begin{tabular}{llcc}
\hline Cultivar & Treatment & $\begin{array}{c}\text { Glyceollin } \\
(\mu \mathrm{g} / \mathrm{g} \mathrm{FW})^{\mathrm{w}}\end{array}$ & $\begin{array}{c}\text { Lesion diam. } \\
(\mathrm{mm})^{\mathrm{x}}\end{array}$ \\
\hline 3 days & & & \\
Williams 82 & Water control & 0.0 & 10.9 \\
& Lactofen $\left(0.11 \mathrm{~kg} \mathrm{ha}^{-1}\right)$ & $7.4^{\mathrm{y}}$ & $6.5^{\mathrm{z}}$ \\
NKS 19-90 & Water control & 0.0 & 10.2 \\
& Lactofen $\left(0.11 \mathrm{~kg} \mathrm{ha}^{-1}\right)$ & $38.2^{\mathrm{y}}$ & $4.6^{\mathrm{z}}$ \\
6 weeks & & & \\
Williams 82 & Water control & 1.7 & 5.8 \\
& Lactofen $\left(0.11 \mathrm{~kg} \mathrm{ha}^{-1}\right)$ & 1.0 & 6.9 \\
NKS 19-90 & Water control & 4.3 & 5.5 \\
& Lactofen $\left(0.11 \mathrm{~kg} \mathrm{ha}^{-1}\right)$ & 2.9 & 5.3
\end{tabular}

$\overline{\mathrm{w}}$ Mean total glyceollin extracted from five leaves per plot harvested from each of four blocks per treatment. FW = fresh weight.

${ }^{\mathrm{x}}$ Lesion diameters measured 2 days after Sclerotinia sclerotiorum inoculation; means of five leaves per plot harvested from each of four blocks per treatment.

y Means significantly $(P<0.05)$ higher than the corresponding water control.

${ }^{\mathrm{z}}$ Means significantly $(P<0.05)$ lower than the corresponding water control. in locations and years in which disease incidence was high. Seed yield reductions after application of lactofen occurred when disease pressure was low to medium, most likely as a result of severe injury caused by treatments. Yield reductions also would have occurred in cases of high disease pressure but were counteracted by the increased protection against Sclerotinia stem rot. Previous studies acknowledged that soybean exhibits foliar injury after diphenyl ether herbicide sprays and that injury increases with increasing lactofen and acifluorfen rates $(13,19)$. In the same studies, yield reductions of 2.5 to $9.8 \%$ occurred in lactofen-treated soybean compared with controls but were apparently not statistically lower. These studies support the current results on the yield-reducing effect of lactofen and demonstrate that a high likelihood of severe Sclerotinia stem rot is required before lactofen should be considered as a disease-suppressing treatment.

Interestingly, lactofen applied at the V4 growth stage in 1997 did not alter disease response, but lactofen applied slightly earlier, at V3 in 1995 and 1996 or at R1 in 1997, resulted in less severe Sclerotinia stem rot. Although herbicide burn was not quantified, injury after the V4 spray in 1997 was not noticeably different than after the V3 spray in 1995 and 1996. It is conceivable that differences between years in environmental conditions (e.g., temperature and humidity) at the time of spraying, onset of infection, and during disease development could have caused the host to respond differently. Further field trials may aid understanding of these complex interactions.

Possible mechanisms involved in lactofen suppression of Sclerotinia stem rot can be proposed based on the current results and mode of action of lactofen. It is unlikely that reduced disease severity occurred because lactofen inhibited S. sclerotiorum directly. Lactofen degrades rapidly under aerobic conditions; the average field half-life is 3 days (1). Thus, it is unlikely that carpogenic germination and production of ascospores would be affected by the small volumes of herbicide that might reach the soil surface. In the plant, lactofen has very limited translocation and is metabolized to biologically inactive residues within 24 days (1), which, if applied at the V3 growth stage, would be prior to ascospore production and infection. Additionally, fieldstrength preparations of lactofen inhibited growth of S. sclerotiorum on PDA by $<20 \%$ compared with water in preliminary studies (results not shown), and the related diphenyl ether herbicide acifluorfen did not significantly inhibit $R$. solani AG-1 in petri dish bioassays (5), suggesting these compounds are not strongly fungicidal.

It is likely that lactofen initiates responses similar to those associated with the hypersensitive response. Lactofen and other diphenyl ether compounds inhibit protoporphyrinogen IX oxidase, (Protox), an enzyme involved in the biosynthesis of heme and

TABLE 3. Resistance response of field soybean leaves 4 days after V4 lactofen treatment in 1997

\begin{tabular}{|c|c|c|c|}
\hline Cultivar & Treatment & $\begin{array}{l}\text { Glyceollin } \\
(\mu g / g \text { FW })^{x}\end{array}$ & $\begin{array}{l}\text { Lesion diam } \\
\qquad(\mathrm{mm})^{\mathrm{y}}\end{array}$ \\
\hline \multirow[t]{4}{*}{ Williams 82} & Water control & $1.5 \mathrm{a}^{\mathrm{z}}$ & $10.5 \mathrm{a}$ \\
\hline & Lactofen, $0.04 \mathrm{~kg} \mathrm{ha}^{-1}$ & $13.4 \mathrm{~b}$ & $5.7 \mathrm{~b}$ \\
\hline & Lactofen, $0.07 \mathrm{~kg} \mathrm{ha}^{-1}$ & $20.9 \mathrm{~b}$ & $6.1 \mathrm{~b}$ \\
\hline & Lactofen, $0.11 \mathrm{~kg} \mathrm{ha}^{-1}$ & $23.8 \mathrm{~b}$ & $4.9 \mathrm{~b}$ \\
\hline \multirow[t]{4}{*}{ NKS19-90 } & Water control & $1.8 \mathrm{a}$ & $8.9 \mathrm{a}$ \\
\hline & Lactofen, $0.04 \mathrm{~kg} \mathrm{ha}^{-1}$ & $36.5 \mathrm{c}$ & $4.7 \mathrm{~b}$ \\
\hline & Lactofen, $0.07 \mathrm{~kg} \mathrm{ha}^{-1}$ & $41.3 \mathrm{c}$ & $4.8 \mathrm{~b}$ \\
\hline & Lactofen, $0.11 \mathrm{~kg} \mathrm{ha}^{-1}$ & $44.8 \mathrm{c}$ & $4.8 \mathrm{~b}$ \\
\hline
\end{tabular}

x Mean total glyceollin extracted from five leaves per plot harvested from each of four blocks per treatment. FW = fresh weight.

${ }^{y}$ Lesion diameters measured 2 days after Sclerotinia sclerotiorum inoculation; means of five leaves per plot harvested from each of four blocks per treatment.

${ }^{\mathrm{z}}$ Means followed by the same letter are not significantly different $(P<0.05)$. 
chlorophyll in the photosynthetic pathway (1). Inhibition of Protox causes protoporphyrinogen IX to accumulate and leak out of plastids and mitochondria and is autoxidized to protoporphyrin. Protoporphyrin is activated by light, resulting in generation of active oxygen species and lipid peroxidation.

This process may explain the accumulation of glyceollin in lactofen-damaged leaves and is strongly supported by a recent study of the involvement of oxidative processes in the initiation of glyceollin synthesis (8). Based on their results, Degousée et al (8) proposed a causal link between lipid peroxidation and synthesis of glyceollin. There are other reports of a close association between production of active oxygen species and phytoalexin accumulation in several plants (3). Glyceollin levels in field leaves of each cultivar increased with increasing lactofen rates in 1997, possibly reflecting the level of injury caused by the treatments, although injury was not assessed quantitatively. Colony growth of S. sclerotiorum on PDA was inhibited by glyceollin concentrations of $10 \mu \mathrm{g} \mathrm{ml}^{-1}$ (results not shown); however, its role in suppressing Sclerotinia stem rot in lactofen-treated soybean has yet to be determined. Because lactofen induces a response that is similar in appearance to the hypersensitive disease resistance response, the induction of other localized defenses and the possibility that lactofen may induce a systemic resistance response is under investigation.

Lactofen also may affect disease severity by altering the canopy environment or reducing sites on the plant that are natural infection courts. Assuming that the disease is initiated primarily through petal infection (11) within the canopy, it is conceivable that any injury resulting in greater air movement and lower humidity in the canopy could reduce the incidence and severity of infection. Additionally, the reduction in disease also could be partially explained by observations of delayed flowering, senescence, and maturity in lactofen-treated plots compared with controls. Further careful ex-

TABLE 4. Sclerotinia stem rot severity and seed yields of field soybeans treated with various herbicides from 1995 to 1997 at two locations in Michigan

\begin{tabular}{|c|c|c|c|c|}
\hline \multirow[b]{2}{*}{ Treatment and stage applied } & \multicolumn{2}{|c|}{ DSI ${ }^{\mathrm{w}}$} & \multicolumn{2}{|c|}{ Yield $\left(\mathrm{t} \mathrm{ha}^{-1}\right)^{\mathrm{x}}$} \\
\hline & Ingham & Bay & Ingham & Bay \\
\hline \multicolumn{5}{|l|}{1995} \\
\hline Water control, V3 & 3.1 & 15.8 & 3.5 & 3.5 \\
\hline Lactofen $0.11 \mathrm{~kg} \mathrm{ha}^{-1}, \mathrm{~V} 3$ & 3.3 & $7.6^{y}$ & $3.1^{\mathrm{y}}$ & 3.3 \\
\hline \multicolumn{5}{|l|}{1996} \\
\hline Water control, V3 & 48.5 & 7.2 & 2.9 & 3.6 \\
\hline Lactofen $0.11 \mathrm{~kg} \mathrm{ha}^{-1}, \mathrm{~V} 3$ & $21.0^{\mathrm{y}}$ & 4.0 & 3.0 & $3.2^{\mathrm{y}}$ \\
\hline Acifluorfen $0.42 \mathrm{~kg} \mathrm{ha}^{-1}, \mathrm{~V} 3$ & $32.8^{\mathrm{y}}$ & 5.2 & 2.9 & 3.4 \\
\hline Fomesafen $0.28 \mathrm{~kg} \mathrm{ha}^{-1}, \mathrm{~V} 3$ & 46.7 & 8.8 & 2.8 & 3.5 \\
\hline Imazethapyr $0.07 \mathrm{~kg} \mathrm{ha}^{-1}, \mathrm{~V} 3$ & 42.6 & 7.1 & $2.5^{\mathrm{y}}$ & 3.2 \\
\hline Bentazon $0.84 \mathrm{~kg} \mathrm{ha}^{-1}, \mathrm{~V} 3$ & 42.3 & 4.8 & 2.8 & 3.5 \\
\hline $\begin{array}{l}\text { Chlorimuron ethyl + thifensulfuror } \\
\text { methyl } 0.004 \mathrm{~kg} \mathrm{ha}^{-1} \text { each, V3 }\end{array}$ & 45.4 & 7.0 & $2.5^{\mathrm{y}}$ & 3.5 \\
\hline \multicolumn{5}{|l|}{1997} \\
\hline Water control, V4 & 48.0 & 19.0 & 2.0 & 3.4 \\
\hline Crop oil control, V4 & 46.3 & 19.9 & 2.0 & 3.5 \\
\hline Crop oil control, R1 & 45.0 & 23.4 & 2.2 & 3.5 \\
\hline Lactofen $0.04 \mathrm{~kg} \mathrm{ha}^{-1}, \mathrm{~V} 4$ & 47.6 & 23.3 & 2.0 & 3.4 \\
\hline Lactofen $0.07 \mathrm{~kg} \mathrm{ha}^{-1}, \mathrm{~V} 4$ & 50.8 & 15.2 & 1.9 & 3.4 \\
\hline Lactofen $0.11 \mathrm{~kg} \mathrm{ha}^{-1}, \mathrm{~V} 4$ & 52.2 & 24.5 & 1.9 & 3.4 \\
\hline Lactofen $0.04 \mathrm{~kg} \mathrm{ha}^{-1}, \mathrm{R} 1$ & $37.6^{\mathrm{y}}$ & 19.3 & 2.1 & $3.2^{\mathrm{y}}$ \\
\hline Lactofen $0.07 \mathrm{~kg} \mathrm{ha}^{-1}, \mathrm{R} 1$ & $28.7^{\mathrm{y}}$ & 21.1 & $2.3^{z}$ & $3.1^{\mathrm{y}}$ \\
\hline Lactofen $0.11 \mathrm{~kg} \mathrm{ha}^{-1}, \mathrm{R} 1$ & $28.8^{\mathrm{y}}$ & 18.3 & $2.4^{\mathrm{z}}$ & $3.2^{\mathrm{y}}$ \\
\hline Lactofen $0.23 \mathrm{~kg} \mathrm{ha}^{-1}, \mathrm{R} 1$ & $32.3^{\mathrm{y}}$ & 14.1 & 2.2 & $3.2^{\mathrm{y}}$ \\
\hline Acifluorfen $0.42 \mathrm{~kg} \mathrm{ha}^{-1}, \mathrm{~V} 4$ & 49.0 & 23.4 & 2.1 & 3.3 \\
\hline Fomesafen $0.25 \mathrm{~kg} \mathrm{ha}^{-1}, \mathrm{~V} 4$ & 46.3 & 17.7 & 2.1 & 3.5 \\
\hline Imazethapyr $0.07 \mathrm{~kg} \mathrm{ha}^{-1}, \mathrm{~V} 4$ & 47.8 & 22.6 & 2.0 & 3.3 \\
\hline
\end{tabular}

${ }^{\mathrm{w}}$ Disease severity index per plot averaged across test cultivars.

${ }^{x}$ Yield per plot, expressed at $13 \%$ moisture, averaged across test cultivars.

${ }^{y}$ Means significantly $(P<0.05)$ lower than the corresponding water control.

${ }^{\mathrm{z}}$ Means significantly $(P<0.05)$ higher than the corresponding water control. perimentation and analyses are necessary to establish any association between canopy environmental conditions and plant development and disease escape.

Interestingly, NK S19-90 had significantly greater levels of glyceollin after lactofen treatment than Williams 82, suggesting NK S19-90 has the capacity for a greater defensive response when stressed or challenged by a pathogen. This conclusion is partially supported by recent studies in which lesions were significantly smaller on NK S19-90 than on Williams 82 leaves excised from plants grown under controlled conditions and inoculated with $S$. sclerotiorum (7). Investigations of other physiological defenses combined with data on plant architecture, maturity, etc., will help elucidate why some cultivars are more resistant than others when grown under field conditions.

Future research will attempt to investigate more closely the mechanism(s) of lactofen-induced Sclerotinia stem rot resistance in soybean. The timing and rate of application for best disease control and higher yields will be optimized. The possible association between the levels of injury and disease suppression will be investigated for lactofen and other injurious diphenyl ether herbicides. Studies of the effect of lactofen on other microorganisms, pathogenic or saprophytic, would be of interest, particularly given the potential widespread use of lactofen as a dual-purpose compound, i.e., as a weed control and as a strategy in integrated control of Sclerotinia stem rot.

\section{ACKNOWLEDGMENTS}

We thank the Michigan Soybean Promotion Committee, North Central Soybean Research Program Board, Michigan Agricultural Experiment Station, and Valent Corporation for financial support.

\section{LITERATURE CITED}

1. Ahrens, W. H., ed. 1994. Herbicide Handbook. 7th ed. Weed Science Society of America, Champaign, IL.

2. Altman, J., and Campbell, C. L. 1977. Effect of herbicides on plant diseases. Annu. Rev. Phytopathol. 15:361-385.

3. Baker, C. J., and Orlandi, E. W. 1995. Active oxygen in plant pathogenesis. Annu. Rev. Phytopathol. 33:299-321.

4. Bhattacharyya, M. K., and Ward, E. W. B. 1985. Differential sensitivity of Phytophthora megasperma f. sp. glycinea isolates to glyceollin isomers. Physiol. Plant Pathol. 27:299-310.

5. Black, B. D., Russin, J. S., Griffin, J. L., and Snow, J. P. 1996. Herbicide effects on Rhizoctonia solani in vitro and Rhizoctonia foliar blight of soybean (Glycine max). Weed Sci. 44:711-716.

6. Casale, W. L., and Hart, L. P. 1986. Influence of four herbicides on carpogenic germination and apothecium development of Sclerotinia sclerotiorum. Phytopathology 76:980-984.

7. Dann, E. K., Diers, B. W., Byrum, J., and Hammerschmidt, R. 1998. Effect of treating soybean with 2,6-dichloroisonicotinic acid (INA) and benzothiadiazole (BTH) on seed yields and the level of disease caused by Sclerotinia sclerotiorum in field and greenhouse studies. Eur. J. Plant Pathol. 104:271-278.

8. Degousée, N., Triantaphylidès, C., and Montillet, J.-L. 1994. Involvement of oxidative processes in the signaling mechanisms leading to the activation of glyceollin synthesis in soybean (Glycine max). Plant Physiol. 104:945-952.

9. Diers, B. W. 1993. Sclerotinia stem rot (white mold) in soybean and the development of resistant varieties. Pages 51-58 in: Proc. 23rd Soybean Res. Conf. D. Wilkinson, ed. American Seed Trade Association, Washington, DC.

10. Fehr, W. H., Caviness, C. E., Burmood, D. T., and Pennington, J. S. 1971. Stage of development descriptions for soybeans, Glycine max (L.) Merrill. Crop Sci. 11:929-931.

11. Grau, C. R. 1988. Sclerotinia stem rot of soybean. Pages 56-66 in: Soybean Diseases of the North Central Region. T. D. Wyllie and D. H. Scott, eds. The American Phytopathological Society, St. Paul, MN.

12. Grau, C. R., Radke, V. L., and Gillespie, F. L. 1982. Resistance of soybean cultivars to Sclerotinia sclerotiorum. Plant Dis. 66:506-508.

13. Harris, J. R., Gossett, B. J., Murphy, T. R., And Toler, J. E. 1991. Response of broadleaf weeds and soybeans to the diphenyl ether herbicides. J. Prod. Agric. 4:407-411. 
14. Holliday, M. J., and Keen, N. T. 1982. The role of phytoalexins in the resistance of soybean leaves to bacteria: Effect of glyphosate on glyceollin accumulation. Phytopathology 72:1470-1474.

15. Katan, J., and Eshel, Y. 1973. Interactions between herbicides and plant pathogens. Residue Rev. 45:145-147.

16. Keen, N. T., Holliday, M. J., and Yoshikawa, M. 1982. Effects of glyphosate on glyceollin production and the expression of resistance to Phytophthora megasperma f. sp. glycinea in soybean. Phyto- pathology 72:1467-1470.

17. Lévesque, C. A., and Rahe, J. E. 1992. Herbicide interactions with fungal root pathogens, with special reference to glyphosate. Annu. Rev. Phytopathol. 30:579-602.

18. Radke, V. L., and Grau, C. R. 1986. Effects of herbicides on carpogenic germination of Sclerotinia sclerotiorum. Plant Dis. 70:19-23.

19. Wichert, R. A., and Talbert, R. E. 1993. Soybean (Glycine max (L.)) response to lactofen. Weed Sci. 41:23-27. 